\title{
Hot Spring Gas Geochemistry in Western Sichuan Province, China After the Wenchuan Ms 8.0 Earthquake
}

\author{
Xiaocheng Zhou ${ }^{1}$, Wanchun Wang ${ }^{2}$, Zhi Chen ${ }^{1}$, Li Yi $^{1}$, Lei Liu ${ }^{1}$, Chao Xie ${ }^{1}$, Yuejü Cui ${ }^{1}$, Jianguo Du$^{1, *}$, \\ Jianwu Cheng ${ }^{3}$, and Liming Yang ${ }^{3}$ \\ ${ }^{1}$ CEA Key Laboratory of Earthquake Prediction (Institute of Earthquake Science), China Earthquake Administration, \\ Beijing, China \\ ${ }^{2}$ Lanzhou Center for Oil and Gas Resources, Institute of Geology and Geophysics, CAS, Lanzhou, China \\ ${ }^{3}$ Earthquake Administration of Gansu Province, Lanzhou, China
}

Received 7 June 2014, revised 28 November 2014, accepted 5 January 2015

\begin{abstract}
The chemical components, $\mathrm{He}, \mathrm{Ne}$, and $\mathrm{C}$ isotropic ratios of gas samples collected thrice from 32 hot springs in western Sichuan Province, southwestern China in June and October 2008 and June 2009 were investigated in order to discuss the relationship between hot spring gas geochemistry and the Wenchuan Ms 8.0 earthquake. The data showed that the ${ }^{3} \mathrm{He} /{ }^{4} \mathrm{He}$ and $\delta^{13} \mathrm{C}_{\mathrm{CO}_{2}}$ values in spring gases in the Longmenshan fault (LMSF), Xianshuihe fault (XSHF), and Minjiang fault (MJF) zones increased obviously after the great earthquake. It was estimated that up to $62 \%$ of mantle helium contributed to the spring gas in the Kangding region based on the maximum ${ }^{3} \mathrm{He} /{ }^{4} \mathrm{He}\left(7.42 \times 10^{-6}\right)$ in June 2008. Over time the mantle derived fluid contribution to the hot springs gradually decreased, but the crustal gas components: $\mathrm{CO}_{2}$ and $\mathrm{CH}_{4}$ derived from organic matter and radiogenic He increased. The gas geochemical data suggested that more mantle fluids migrated into the crust in western Sichuan Province after the Wenchuan Ms 8.0 earthquake.
\end{abstract}

Key words: Gas geochemistry, Earthquake, Hot spring, Isotopic ratios, Wenchuan

Citation: Zhou, X., W. Wang, Z. Chen, L. Yi, L. Liu, C. Xie, Y. Cui, J. Du, J. Cheng, and L. Yang, 2015: Hot spring gas geochemistry in western Sichuan Province, China after the Wenchuan Ms 8.0 earthquake. Terr. Atmos. Ocean. Sci., 26, 361-373, doi: 10.3319/TAO.2015.01.05.01(TT)

\section{INTRODUCTION}

The Wenchuan Ms 8.0 earthquake occurred on 12 May 2008 in the Longmenshan fault (LMSF) zone at the eastern margin of Tibet plateau. The aftershocks were distributed along the NE strike surface rupture zone of about $270 \mathrm{~km}$ long (Fig. 1) (Li et al. 2010).

Earthquakes are usually accompanied with geochemical variations of gases from hot springs. The obvious variations of gas geochemistry related to the great earthquakes have been found around the world, especially in active fault zones in which permeability was enhanced (Du et al. 2008a; Bräuer et al. 2009). Gas components, such as $\mathrm{CO}_{2}, \mathrm{He}, \mathrm{H}_{2}$, $\mathrm{Rn}, \mathrm{N}_{2}$, gaseous hydrocarbons, etc. in the lithosphere can be expelled to the surface during the earthquake genetic process (Sano et al. 1998; Umeda et al. 2007; Du et al. 2008b; Italiano et al. 2009). For example, geochemical anomalies

\footnotetext{
* Corresponding author

E-mail:jianguodu@hotmail.com
}

coinciding with seismic events in Umbria (central Apennines, Italy) and Irpinia (Southern Apennines) were not only related simply to the seismic shocks, but also to the entire seismogenic processes (Favara et al. 2001; Italiano et al. 2009). Consequently, geothermal zones are usually characterized by higher heat flow value, with active faults have acted or are acting since 1000 ka before now, with the seismic zones overlapped (Du et al. 2008b).

$\mathrm{He}$ and $\mathrm{C}$ isotopic compositions in geothermal fluids carry useful information about the fluid origins and migration processes. Therefore, $\mathrm{He}$ and $\mathrm{C}$ isotopic geochemistry has been widely utilized in monitoring earthquakes and volcanoes (Sano et al. 1998; Tedesco and Scarsi 1999; Bräuer et al. 2005; Umeda et al. 2007; Yang et al. 2009). The $\delta^{13} \mathrm{C}_{\mathrm{CO}_{2}}$ and ${ }^{3} \mathrm{He} /{ }^{4} \mathrm{He}$ values studied in the hot springs in western Sichuan Province varied significantly in the different earthquake zones. The $\mathrm{He}$ and $\mathrm{C}$ isotopic ratios of hot spring gases in the Kangding and Luding regions, western Sichuan Province indicated that a lot of mantle derived fluids mixed with fluids 
originating from the crust (Du et al. 2006; Shen et al. 2007).

The study aims at correlating hot spring gas geochemistry with the Wenchuan Ms 8.0 earthquake.

\section{SEISMOGEOLOGICAL SETTING}

On 12 May 2008 (06:28:01 UTC) the devastating Wenchuan earthquake (Ms 8.0) struck at the center of the LMSF zone. This fault zone presents a complex structure including several large thrust faults with 250 - $300 \mathrm{~km}$ lateral extension (Fig. 1). The shock was characterized by its long time duration, extensive fault surface rupture and shallow hypocenter depth $(\sim 16 \mathrm{~km})$ The shock epicenter was about $90 \mathrm{~km}$ west of Chengdu, the largest city and capital of Sichuan province in southwest China (Wang et al. 2011). Five major faults exist in western Sichuan Province, named the LMSF, Minjiang fault (MJF), Xianshuihe fault (XSHF), Anninghe fault (ANHF), and Zemuhe fault (ZMHF) (Fig. 1) (Tang and Han 1993; Wen et al. 2008). The LMSF zone with a NE strike began to develop in the Triassic period. Due to episodic movements during the Mesozoic and Cenozoic Eras, especially since the Late Cenozoic Era, accompanied by eastward extrusion of the Qinghai-Tibet Plateau, the middle and southern segments of the LMSF zone have undergone strong compression. Strata in the fault zone are predominantly Palaeozoic and early Mesozoic flysch and limestone, interbeded with volcanic rocks (Tang and Han 1993; Burchfiel et al. 1995). The NS strike MJF developed along the Min-Jiang River on the western margin of the Min Mountains, of which the southern end is connected with the central Longmen Mountains (Tang and Han 1993). The XSHF presents a strike-slip feature and trends $40^{\circ} \mathrm{N}-50^{\circ} \mathrm{W}$ with a steep southwest dip. It extends from Ganzi, crosses through the towns of Luhuo, Daofu, Kangding to Shimian (Fig. 1). The XSHF zone has a long history of highly ductile shear zones consisting of mylonite, mylonitized, and magmatic rocks. The XSHF left-laterally offsets a huge Pre-Cambrian (700 - $800 \mathrm{Ma}$ ) metamorphic complex belt for $90-100 \mathrm{~km}$ with an emplaced granodiorite body (Tang and Han 1993). The NS strike ANHF from Shimian to Xichang is characterized by severe activity in the Holocene period. The length of fault is about $160 \mathrm{~km}$ with prominent left-lateral slip (Ran et al. 2008). The northern ZMHF segment has a NNW strike connected to the ANHF, and its southern end joins the Daliangshan fault (Fig. 1). The basement along the ZMHF zone consists mainly of metamorphic rocks derived from Pre-Cambrian granite and rhyolite, along with Permian basalt and Triassic granite (Fig. 1). Cenozoic strata (Late Tertiary to Early Quaternary) consist mainly of interbedded mudstones and sandstones with thin layers of coal (Ren et al. 2010).

Great earthquakes have occurred frequently in western Sichuan Province since 1800 A.D., and nine M > 7.5 earthquakes are the 1850 Xichang Ms 7.5, 1954 Litang Ms 7.2, 1955 Kangding M 7.5, 1967 Zhuwei Ms 6.8, 1973 Luhuo Ms 7.9, 1976 Songpan Ms 7.2, 1981 Daofu Ms 6.9, 2008 Wenchuan Ms 8.0 ones and 2013 Lushan Ms 7.0 earthquakes (Wen et al. 2008).

\section{METHODS}

A total of 84 samples of free and dissolved gases were collected repeatedly from 32 hot springs and wells in western Sichuan Province (Fig. 1). Samples were collected in June, October 2008, and June 2009, respectively. Samples

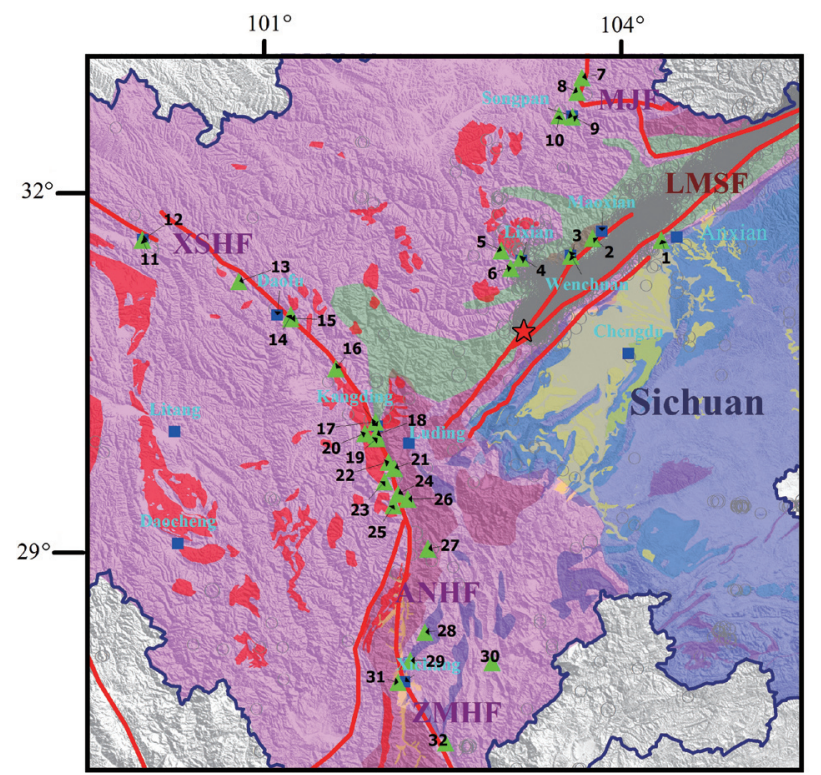

\section{Legend}

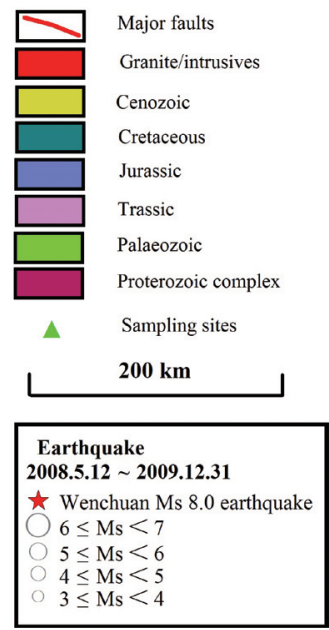

Fig. 1. Location of the sampling sites and the main fault zones in western Sichuan Province together with the epicentres of the 2008 Wenchuan Ms 8.0 earthquake and aftershocks. 
were collected only from the free gas phase, using vessels $(500 \mathrm{ml})$ made of soda-lime glass as this type of glass has very low helium permeability. The vessels were first filled with spring water with gas bubbles collected using a funnel, replacing the water in the vessel. The vessels were sealed with a rubber plug (Du et al. 2006). The dissolved gases were extracted from water samples stored in vessels utilizing a technique based on partitioning equilibrium of gas species between the liquid and gas phases. Duplicate samples were collected; one for gas composition measurement and the second for analyzing isotope ( $\mathrm{He}$ and $\mathrm{C}$ ) ratios.

The spring water temperatures were measured with a thermometer having an accuracy of $0.1^{\circ} \mathrm{C}$. All gas samples were analyzed at the Key Laboratory of Petroleum Resources Research, Institute of Geology and Geophysics, Chinese Academy of Sciences. The gas sample compositions were analyzed with a Finnigan MAT-271 mass spectrometer, with a precision of $\pm 0.1 \%$. The MAT-271 instrument parameters were adjusted to an ion source pressure of $8.0 \mathrm{kV}$, an emission current of $40 \mu \mathrm{A}$ and vacuum maintained less than $1.0 \times 10^{-7} \mathrm{~Pa}$ (Reber and Cordes 1995; Cao et al. 2011). He and $\mathrm{Ne}$ isotopes in the gas samples were measured using the MM5400 mass spectrometer. The minimum heat blanks of the MM5400 mass spectrometer are $1.1 \times 10^{-14}$ for ${ }^{4} \mathrm{He}$ and $1.82 \times 10^{-14}$ for ${ }^{20} \mathrm{Ne}$, respectively (Ye et al. 2007). The measurements were normalized to standard atmospheric value (Ye et al. 2001). Carbon isotope compositions of $\mathrm{CH}_{4}$ and $\mathrm{CO}_{2}$ in the gas samples were measured with the GC-IRMS analytical system gas chromatography (Agilent 6890)-stable isotope ratio mass spectrometer (Thermo-Fisher Scientific
Delta Plus XP), coupled with an online sample preprocessor (Li et al. 2007). Methane and carbon dioxide were separated on a GC for stable carbon isotope analyses. The methane was combusted over hot copper oxide $\left(940^{\circ} \mathrm{C}\right)$, and the carbon dioxide produced by the system was transmitted to the mass spectrometer ( $\mathrm{Li}$ et al. 2012). The GC parameters were as follows: an Agilent 6890 GC equipped with a fused silica capillary column coated with carbon molecular sieve stationary phase $(25 \mathrm{~m} \times 0.53 \mathrm{~mm} \times 20 \mu \mathrm{m}$, CP-Carbobond, Varian, U.S.A.) was used to separate the samples with a helium carrier gas (purity $\geq 99.9999 \%$ ) at a constant flow of $4 \mathrm{~mL} \mathrm{~min}^{-1}$. The GC split ratio was 4:1. The GC temperature programming were as follows: the initial temperature was set to $35^{\circ} \mathrm{C}$ for 3 minutes, followed by heating to $280^{\circ} \mathrm{C}$ at a rate of $15^{\circ} \mathrm{C} \mathrm{m^{-1 }}$ for 10 minutes. The values of $\delta^{13} \mathrm{C}$ are reported relative to PDB in per mill, and had a precision of $\pm 0.5 \%$.

\section{RESULTS}

The chemical and isotopic compositions of both bubbling and dissolved presented wider ranges and varied in the different fault zones both in the same period and different periods (Table 1).

\subsection{Chemical Composition of the Spring Gases}

$\mathrm{CO}_{2}$ concentrations of the bubbling gas samples ranged from $1.2-98.8 \mathrm{vol} \%$, of which the majority was more than $85 \mathrm{vol} \%$. The gas samples collected in Anxian County presented the majority of $\mathrm{CH}_{4}$. The $\mathrm{N}_{2}$ and $\mathrm{O}_{2}$ concentrations

Table 1. Sampling location and time, water temperature, gas type, isotope, and gas composition of the samples in the hot spring gases in western Sichuan.

\begin{tabular}{|c|c|c|c|c|c|c|c|c|c|c|c|c|c|c|c|c|c|}
\hline \multirow[b]{2}{*}{ No. ${ }^{a}$} & \multicolumn{2}{|c|}{ Sample } & \multirow{2}{*}{$\begin{array}{c}\text { Date } \\
\left(\mathbf{y ~ m}^{-1}\right)\end{array}$} & \multirow{2}{*}{$\begin{array}{c}\mathbf{T} \\
\left({ }^{\circ} \mathbf{C}\right)\end{array}$} & \multirow{2}{*}{$\mathbf{X}^{\mathrm{c}}$} & \multirow{2}{*}{$\mathbf{R}_{\mathrm{m}} / \mathbf{R a}^{\mathrm{d}}$} & \multirow{2}{*}{$\mathbf{R}_{\mathrm{c}} / \mathbf{R a}^{\mathrm{e}}$} & \multicolumn{2}{|c|}{$\delta^{13} \mathrm{C}_{\mathrm{PDB}} \% 0$} & \multicolumn{6}{|c|}{ Compositions (\%) } & \multirow{2}{*}{$\begin{array}{c}\mathrm{CO}_{2}{ }^{\beta} \mathrm{He} \\
\left(\times \mathbf{1 0}^{9}\right)\end{array}$} & \multirow{2}{*}{$\begin{array}{c}\mathrm{CH}_{4} /{ }^{\beta} \mathrm{He} \\
\left(\times 10^{6}\right) \\
\end{array}$} \\
\hline & location & Type $^{\text {b }}$ & & & & & & $\mathrm{CH}_{4}$ & $\mathrm{CO}_{2}$ & ${ }^{4} \mathrm{He}$ & $\mathrm{CH}_{4}$ & $\mathbf{N}_{2}$ & $\mathrm{O}_{2}$ & Ar & $\mathrm{CO}_{2}$ & & \\
\hline \multirow{3}{*}{1} & \multirow{3}{*}{ Sangzao } & \multirow{3}{*}{ B } & $08 / 07$ & 19.0 & - & $0.16 \pm 0.01$ & - & -51.7 & -15.7 & 0.0930 & 56.8 & 41.1 & 0.1 & 0.5 & 1.2 & 0.06 & 2726 \\
\hline & & & $08 / 11$ & 19.1 & 319.13 & $0.12 \pm 0.00$ & 0.12 & -52.2 & -16.5 & 0.1600 & 53.4 & 43.6 & 1.0 & 0.6 & 1.2 & 0.04 & 1986 \\
\hline & & & $09 / 07$ & 19.7 & 601.67 & $0.02 \pm 0.00$ & 0.02 & -51.6 & -15.6 & 0.1470 & 47.3 & 48.5 & 0.8 & 0.6 & 2.7 & 0.66 & 11491 \\
\hline \multirow{3}{*}{2} & \multirow{3}{*}{ Jiyu } & \multirow{3}{*}{ D } & $08 / 06$ & 32.9 & - & $0.08 \pm 0.00$ & - & 9.2 & -10.7 & 0.2270 & 0.0 & 88.6 & 6.7 & 1.1 & 3.5 & 0.14 & - \\
\hline & & & $08 / 10$ & 29.5 & 178.24 & $0.04 \pm 0.00$ & 0.03 & - & -12.2 & 0.0328 & 0.0 & 85.4 & 11.4 & 1.1 & 2.2 & 1.20 & - \\
\hline & & & $09 / 06$ & 27.1 & 278.57 & $0.04 \pm 0.00$ & 0.04 & -26.1 & -12.1 & 0.0175 & 0.0 & 92.6 & 3.0 & 1.2 & 3.2 & 3.27 & - \\
\hline \multirow{2}{*}{3} & \multirow{2}{*}{ WS } & \multirow{2}{*}{ D } & $08 / 10$ & 15.4 & 1.99 & $1.61 \pm 0.03$ & 2.20 & - & -14.6 & 0.0004 & 0.0 & 79.7 & 17.4 & 1.0 & 2.0 & 2.23 & - \\
\hline & & & $09 / 06$ & 15.5 & 1.38 & $0.94 \pm 0.04$ & 0.78 & - & -17.2 & 0.0000 & 0.0 & 81.3 & 16.4 & 1.0 & 1.3 & - & - \\
\hline \multirow{3}{*}{4} & \multirow{3}{*}{ LS } & \multirow{3}{*}{$\mathrm{D}$} & 08/06 & 30.5 & - & $0.33 \pm 0.01$ & - & -6.7 & -14 & 0.0145 & 0.0 & 83.0 & 8.8 & 1.1 & 7.0 & 1.04 & - \\
\hline & & & $08 / 10$ & 32.1 & 109.56 & $0.07 \pm 0.00$ & 0.06 & -21.8 & -14.3 & 0.0595 & 0.0 & 78.9 & 20.0 & 1.0 & 0.1 & 0.02 & - \\
\hline & & & 09/06 & 32.0 & 3.70 & $0.66 \pm 0.02$ & 0.53 & - & -13.3 & 0.0004 & 0.0 & 88.5 & 3.7 & 1.1 & 6.7 & 18.13 & - \\
\hline
\end{tabular}

Note: a: WS: Wenchuan Seismostation, LS: Lixian Seismostation, SS: Songpan Seismostation, GS: Ganzi Seismostation, LPG1: Longpugou No. 1, LPG2: Longpugou No. 2, SMS: Shimian Seismostation; '-' represent no data. b: $B=$ Bubbling gas, $D=$ Dissolved gas. $c: X$-value Bubbling gas $=\left({ }^{4} H e e^{20} N e\right)_{\text {measured }} /$ $\left({ }^{4} \mathrm{He}{ }^{20} \mathrm{Ne}\right)_{\text {air }} \times X$-value Dissolved gas $=\left({ }^{4} \mathrm{He}{ }^{20} \mathrm{Ne}\right)_{\text {measured }} /\left[\left({ }^{4} \mathrm{He}{ }^{20} \mathrm{Ne}\right)_{\text {air }} \times\left(\beta_{\mathrm{Ne}} / \beta_{\mathrm{He}}\right)\right]$, where $\beta=$ Bunsen solubility coefficient. For pure water at $15^{\circ} \mathrm{C}\left(\beta_{\mathrm{Ne}} / \beta_{\mathrm{He}}\right)$ $=1.22$ (Weiss 1971). See Hilton (1996) for further details of the correction protocol. $d: R_{m} /$ Ra is measured ${ }^{3} \mathrm{He} /{ }^{4} \mathrm{He}$ ratio divided by the ${ }^{3} \mathrm{He}{ }^{4} \mathrm{He}$ in air $=1.4 \times 10^{-6} . e: R_{c} /$ Ra is the air corrected He isotope ratio $=\left[\left(R_{m} / R a \times X\right)-1\right] /(X-1)$. 
Table 1. (Continued)

\begin{tabular}{|c|c|c|c|c|c|c|c|c|c|c|c|c|c|c|c|c|c|}
\hline \multirow[b]{2}{*}{ No. ${ }^{a}$} & \multicolumn{2}{|c|}{ Sample } & \multirow{2}{*}{$\begin{array}{c}\text { Date } \\
\left(\mathbf{y ~ m}^{-1}\right)\end{array}$} & \multirow{2}{*}{$\begin{array}{c}\mathbf{T} \\
\left({ }^{\circ} \mathbf{C}\right)\end{array}$} & \multirow{2}{*}{$\mathbf{X}^{\mathrm{c}}$} & \multirow{2}{*}{$\mathbf{R}_{\mathrm{m}} / \mathbf{R a}^{\mathbf{d}}$} & \multirow{2}{*}{$\mathbf{R}_{\mathrm{c}} / \mathbf{R a}^{\mathrm{e}}$} & \multicolumn{2}{|c|}{$\delta^{13} \mathrm{C}_{\mathrm{PDB}} \% o$} & \multicolumn{6}{|c|}{ Compositions (\%) } & \multirow{2}{*}{$\begin{array}{c}\mathrm{CO}_{2} / 3 \mathrm{He} \\
\left(\times 10^{9}\right)\end{array}$} & \multirow{2}{*}{$\begin{array}{c}\mathrm{CH}_{4} /{ }^{3} \mathbf{H e} \\
\left(\times \mathbf{1 0}^{6}\right)\end{array}$} \\
\hline & location & Type $^{\text {b }}$ & & & & & & $\mathrm{CH}_{4}$ & $\mathrm{CO}_{2}$ & ${ }^{4} \mathrm{He}$ & $\mathrm{CH}_{4}$ & $\mathbf{N}_{2}$ & $\mathrm{O}_{2}$ & Ar & $\mathrm{CO}_{2}$ & & \\
\hline \multirow{3}{*}{5} & \multirow{3}{*}{ Guergou } & \multirow{3}{*}{$\mathrm{D}$} & $08 / 06$ & 56.5 & - & $0.12 \pm 0.00$ & - & -25.1 & -15.1 & 0.1400 & 0.0 & 90.0 & 8.8 & 1.1 & 0.0 & - & - \\
\hline & & & $08 / 10$ & 58.0 & 1.67 & $0.23 \pm 0.06$ & 0.92 & - & -9 & 0.0000 & 0.0 & 79.5 & 19.3 & 1.0 & 0.3 & - & - \\
\hline & & & $09 / 06$ & 56.0 & 126.47 & $0.06 \pm 0.01$ & 0.05 & -22.6 & -4.1 & 0.0564 & 1.0 & 94.6 & 1.4 & 1.6 & 1.5 & 0.32 & 211.08 \\
\hline 6 & Jiasikou & D & $09 / 06$ & 34.0 & 1.79 & $1.01 \pm 0.02$ & 1.02 & - & -7.6 & 0.0004 & 0.6 & 67.6 & 9.1 & 0.9 & 21.8 & 38.54 & 1060.82 \\
\hline \multirow{3}{*}{7} & \multirow{3}{*}{ Kakagou } & \multirow{3}{*}{ D } & $08 / 06$ & 18.7 & - & $0.55 \pm 0.01$ & - & - & -4.5 & 0.0033 & 0.0 & 54.1 & 5.5 & 0.6 & 39.8 & 15.66 & - \\
\hline & & & $08 / 10$ & 19.7 & 25.78 & $0.61 \pm 0.04$ & 0.59 & - & -6 & 0.0005 & 0.0 & 60.2 & 11.6 & 0.7 & 27.5 & 64.40 & - \\
\hline & & & 09/06 & 21.7 & 32.17 & $0.18 \pm 0.01$ & 0.15 & - & -6.6 & 0.0010 & 0.0 & 38.2 & 2.4 & 0.4 & 58.9 & 233.7 & - \\
\hline & & & $08 / 06$ & 8.8 & - & $1.68 \pm 0.05$ & - & -34.6 & -1.9 & 0.0004 & 0.0 & 7.0 & 1.5 & 0.1 & 91.5 & 97.2 & - \\
\hline 8 & Chuanpan- & B & $08 / 10$ & 9.6 & 36.13 & $0.52 \pm 0.02$ & 0.51 & -23.8 & -3.9 & 0.0001 & 0.0 & 1.5 & 0.4 & 0.0 & 98.1 & 1347.5 & - \\
\hline & & & $09 / 06$ & 10.7 & 34.33 & $0.27 \pm 0.03$ & 0.25 & -40.7 & -3.4 & 0.0001 & 0.0 & 4.8 & 1.1 & 0.1 & 94.1 & 2489.4 & - \\
\hline & & & $08 / 06$ & 9.0 & - & $0.65 \pm 0.03$ & - & - & -14.3 & 0.0015 & 0.0 & 82.5 & 14.8 & 1.0 & 1.7 & 1.25 & - \\
\hline 9 & SS & $\mathrm{D}$ & $08 / 10$ & 9.5 & 1.79 & $1.79 \pm 0.11$ & 2.79 & - & -14.3 & 0.0001 & 0.0 & 80.0 & 17.7 & 1.0 & 1.3 & 5.19 & - \\
\hline & & & 09/06 & 9.3 & 1.67 & $0.78 \pm 0.06$ & 0.45 & - & -14.9 & 0.0001 & 0.0 & 67.6 & 12.6 & 0.9 & 18.9 & 173.0 & - \\
\hline & & & $08 / 06$ & 21.6 & - & $2.16 \pm 0.07$ & - & -24.7 & -4.2 & 0.0004 & 0.0 & 12.2 & 3.1 & 0.2 & 84.5 & 69.8 & - \\
\hline 10 & Mounigou & B & $08 / 10$ & 20.7 & 11.97 & $0.13 \pm 0.02$ & 0.05 & -30.5 & -5.5 & 0.0000 & 0.0 & 4.3 & 1.1 & 0.1 & 94.6 & 5197.8 & - \\
\hline & & & 09/06 & 20.0 & 17.83 & $0.59 \pm 0.1$ & 0.57 & -15.2 & -6.6 & 0.0001 & 0.0 & 5.9 & 1.0 & 0.1 & 93.0 & 1125.9 & - \\
\hline & & & $08 / 06$ & 48.1 & - & $0.14 \pm 0.00$ & - & -36.3 & -11.3 & 0.0512 & 2.0 & 83.1 & 6.0 & 0.9 & 7.9 & 0.79 & 199.30 \\
\hline 11 & Leyuan & D & $08 / 10$ & 51.5 & 116.10 & $0.18 \pm 0.00$ & 0.17 & -33 & -11.7 & 0.0288 & 5.1 & 75.7 & 7.8 & 1.2 & 10.2 & 1.41 & 702.71 \\
\hline & & & 09/06 & 43.0 & 100.45 & $0.2 \pm 0.00$ & 0.19 & -34 & -12 & 0.0178 & 7.8 & 78.2 & 0.2 & 1.0 & 12.7 & 2.55 & 1565 \\
\hline & & & $08 / 06$ & 27.8 & - & $0.21 \pm 0.00$ & - & -24.8 & -11.6 & 0.0629 & 0.4 & 87.8 & 7.5 & 1.1 & 3.2 & 0.17 & 21.63 \\
\hline 12 & GS & B & $08 / 10$ & 29.8 & 126.47 & $0.19 \pm 0.00$ & 0.18 & -12.8 & -13.7 & 0.0648 & 0.4 & 93.7 & 0.8 & 1.1 & 3.9 & 0.23 & 23.21 \\
\hline & & & 09/06 & 29.6 & 106.67 & $0.23 \pm 0.01$ & 0.22 & -14 & -14.2 & 0.0506 & 0.3 & 94.0 & 0.6 & 1.1 & 4.0 & 0.25 & 18.41 \\
\hline & & & $08 / 06$ & 37.5 & - & $4.27 \pm 0.08$ & - & -54 & -2.6 & 0.0006 & 0.1 & 8.9 & 1.9 & 0.1 & 88.9 & 24.79 & 27.88 \\
\hline 13 & Guyi & B & $08 / 10$ & 31.3 & 14.90 & $0.17 \pm 0.01$ & 0.11 & - & -5.3 & 0.0002 & 0.0 & 2.5 & 0.4 & 0.0 & 97.0 & 2037.8 & - \\
\hline & & & 09/06 & 43.2 & 1.23 & $1.14 \pm 0.2$ & 1.74 & - & -7 & 0.0004 & 0.0 & 69.5 & 1.4 & 0.9 & 28.2 & 44.17 & - \\
\hline & & & $08 / 06$ & 37.8 & - & $0.18 \pm 0.00$ & - & -51.9 & -9.6 & 0.0225 & 2.1 & 59.5 & 8.3 & 0.7 & 29.5 & 5.20 & 370.37 \\
\hline 14 & LPG1 & D & $08 / 10$ & 37.2 & 121.31 & $0.19 \pm 0.00$ & 0.18 & -32.7 & -10 & 0.0104 & 2.1 & 59.5 & 11.9 & 0.8 & 25.7 & 9.29 & 759.11 \\
\hline & & & 09/06 & 39.2 & 106.95 & $0.22 \pm 0.01$ & 0.21 & -32.3 & -8.8 & 0.0124 & 4.4 & 29.1 & 1.3 & 0.5 & 64.7 & 16.94 & 1152 \\
\hline & & & $08 / 06$ & 44.5 & - & $0.29 \pm 0.01$ & - & - & -9.8 & 0.0098 & 0.0 & 68.8 & 13.5 & 0.9 & 16.8 & 4.22 & - \\
\hline 15 & LPG2 & D & $08 / 10$ & 42.5 & 24.97 & $0.14 \pm 0.00$ & 0.10 & - & - & 0.0002 & 0.0 & 65.0 & 6.8 & 1.0 & 27.2 & 693.88 & - \\
\hline & & & 09/06 & 42.5 & 11.79 & $0.31 \pm 0.01$ & 0.25 & -27.6 & -10.1 & 0.2480 & 0.3 & 61.5 & 7.0 & 0.9 & 30.3 & 0.28 & 2.79 \\
\hline & & & $08 / 06$ & 55.2 & - & $1.66 \pm 0.05$ & - & -31.3 & -5.3 & 0.0005 & 0.2 & 15.5 & 3.8 & 0.2 & 80.4 & 69.19 & 172.12 \\
\hline 16 & Bamei & B & $08 / 10$ & 55.0 & 126.43 & $0.34 \pm 0.01$ & 0.33 & -30.1 & -8 & 0.0003 & 0.1 & 3.4 & 0.9 & 0.0 & 95.6 & 669.47 & 700.28 \\
\hline & & & 09/06 & 56.0 & 28.37 & $2.11 \pm 0.05$ & 2.15 & -29.7 & -9 & 0.0002 & 0.4 & 2.2 & 0.3 & 0.0 & 97.1 & 164.35 & 677.05 \\
\hline & & & 08/06 & 39.1 & - & $3.57 \pm 0.03$ & - & -2.4 & -3.8 & 0.0010 & 0.0 & 9.2 & 1.9 & 0.1 & 88.7 & 17.75 & - \\
\hline 17 & Erdaoqiao & B & $08 / 10$ & 39.4 & 62.20 & $2.71 \pm 0.05$ & 2.74 & 1.4 & $-6 . .5$ & 0.0003 & 0.0 & 2.8 & 0.4 & 0.1 & 96.6 & 84.87 & - \\
\hline & & & 09/06 & 40.6 & 39.33 & $2.89 \pm 0.17$ & 2.94 & 2.4 & -7.5 & 0.0003 & 0.0 & 6.5 & 0.0 & 0.0 & 70.8 & 5.36 & 58329 \\
\hline & & & $08 / 06$ & 70.8 & - & $5.33 \pm 0.14$ & - & -26.7 & -3.3 & 0.0005 & 0.0 & 22.0 & 5.8 & 0.3 & 71.9 & 19.27 & - \\
\hline 18 & $\begin{array}{c}\text { Longtou- } \\
\text { gou }\end{array}$ & B & $08 / 10$ & 70.8 & 11.90 & $1.43 \pm 0.11$ & 1.47 & -22.5 & -7.5 & 0.0000 & 0.0 & 4.1 & 1.1 & 0.1 & 94.7 & 473 & - \\
\hline & & & 09/06 & 73.1 & 17.63 & $0.9 \pm 0.22$ & 0.89 & -24 & -7.9 & 0.0001 & 0.1 & 2.1 & 0.4 & 0.0 & 97.3 & 772.22 & 793.65 \\
\hline & & & $08 / 06$ & 80.5 & 0.00 & $3.35 \pm 0.11$ & - & -27.3 & -3.6 & 0.0006 & 0.1 & 39.3 & 10.1 & 0.5 & 50.1 & 17.80 & 35.54 \\
\hline 19 & Guanding & B & $08 / 10$ & 80.0 & 86.97 & $2.85 \pm 0.09$ & 2.87 & -23.7 & -8 & 0.0002 & 0.1 & 9.0 & 2.2 & 0.1 & 88.6 & 111.03 & 125.31 \\
\hline & & & 09/06 & 83.0 & 41.67 & $3.73 \pm 0.45$ & 3.80 & -23.3 & -7.5 & 0.0004 & 0.2 & 0.9 & 0.1 & 0.0 & 98.8 & 47.30 & 95.75 \\
\hline 20 & $\begin{array}{l}\text { Zhed- } \\
\text { uotang }\end{array}$ & D & 09/06 & 53.4 & 3.54 & $1.01 \pm 0.06$ & 1.01 & 5.6 & -14 & 0.0008 & 0.0 & 79.0 & 16.3 & 1.2 & 3.4 & 3.01 & - \\
\hline
\end{tabular}


Table 1. (Continued)

\begin{tabular}{|c|c|c|c|c|c|c|c|c|c|c|c|c|c|c|c|c|c|}
\hline \multirow[b]{2}{*}{ No. ${ }^{a}$} & \multicolumn{2}{|c|}{ Sample } & \multirow{2}{*}{$\begin{array}{c}\text { Date } \\
\left(\mathbf{y ~ m}^{-1}\right)\end{array}$} & \multirow{2}{*}{$\begin{array}{c}\mathbf{T} \\
\left({ }^{\circ} \mathbf{C}\right)\end{array}$} & \multirow{2}{*}{$X^{c}$} & \multirow{2}{*}{$\mathbf{R}_{\mathrm{m}} / \mathbf{R a}^{\mathrm{d}}$} & \multirow{2}{*}{$\mathbf{R}_{\mathrm{c}} / \mathbf{R a}^{\mathrm{e}}$} & \multicolumn{2}{|c|}{$\delta^{13} \mathbf{C}_{\mathrm{PDB}} \% o$} & \multicolumn{6}{|c|}{ Compositions (\%) } & \multirow{2}{*}{$\begin{array}{c}\mathrm{CO}_{2}{ }^{\beta} \mathrm{He} \\
\left(\times 10^{9}\right)\end{array}$} & \multirow{2}{*}{$\begin{array}{c}\mathrm{CH}_{4} /{ }^{\beta} \mathbf{H e} \\
\left(\times 10^{6}\right)\end{array}$} \\
\hline & location & Type $^{\text {b }}$ & & & & & & $\mathrm{CH}_{4}$ & $\mathrm{CO}_{2}$ & ${ }^{4} \mathrm{He}$ & $\mathrm{CH}_{4}$ & $\mathbf{N}_{2}$ & $\mathrm{O}_{2}$ & Ar & $\mathrm{CO}_{2}$ & & \\
\hline \multirow{3}{*}{21} & \multirow{3}{*}{ Moxi } & \multirow{3}{*}{ B } & $08 / 06$ & 48.8 & - & $0.68 \pm 0.02$ & - & -20.6 & -9.8 & 0.0921 & 2.7 & 82.3 & 0.3 & 1.5 & 13.3 & 0.15 & 30.79 \\
\hline & & & $08 / 10$ & 47.6 & 176.30 & $1.16 \pm 0.01$ & 1.16 & -16.9 & -14.9 & 0.0676 & 2.3 & 88.4 & 0.6 & 1.2 & 7.5 & 0.07 & 20.95 \\
\hline & & & $09 / 06$ & 50.0 & 146.00 & $1.39 \pm 0.01$ & 1.39 & -30.9 & -12.1 & 0.0907 & 2.6 & 89.4 & 0.8 & 1.2 & 6.0 & 0.03 & 14.73 \\
\hline \multirow{3}{*}{22} & \multirow{3}{*}{ Xinxing } & \multirow{3}{*}{$\mathrm{D}$} & $08 / 06$ & 45.6 & - & $0.58 \pm 0.02$ & - & -32.2 & -11.6 & 0.1368 & 3.6 & 78.4 & 10.9 & 1.1 & 5.9 & 0.05 & 32.41 \\
\hline & & & $08 / 10$ & 44.1 & 442.98 & $1.07 \pm 0.01$ & 1.07 & -31.5 & -12.8 & 0.1445 & 8.0 & 81.2 & 1.9 & 1.3 & 7.6 & 0.04 & 36.96 \\
\hline & & & 09/06 & 42.8 & 459.13 & $1.28 \pm 0.05$ & 1.28 & -30.3 & -13.1 & 0.1620 & 5.9 & 83.2 & 1.4 & 1.2 & 8.2 & 0.03 & 20.32 \\
\hline \multirow{3}{*}{23} & \multirow{3}{*}{$\begin{array}{c}\text { Erhaoy- } \\
\text { ingdi }\end{array}$} & \multirow{3}{*}{$\mathrm{B}$} & $08 / 06$ & 51.5 & - & $1.93 \pm 0.02$ & - & -24.1 & -3.7 & 0.0019 & 0.6 & 6.8 & 0.7 & 0.2 & 91.7 & 17.86 & 116.87 \\
\hline & & & $08 / 10$ & 69.1 & 75.30 & $1.45 \pm 0.06$ & 1.46 & -21.5 & -5.3 & 0.0006 & 0.1 & 2.8 & 0.3 & 0.1 & 96.6 & 79.31 & 82.10 \\
\hline & & & 09/06 & 73.0 & 10.43 & $0.61 \pm 0.14$ & 0.57 & -23.4 & -7.5 & 0.0007 & 0.6 & 13.4 & 0.3 & 0.2 & 85.6 & 143.19 & 1003 \\
\hline 24 & $\begin{array}{c}\text { Lianghek- } \\
\text { ou }\end{array}$ & D & 08/06 & 53.0 & - & $0.68 \pm 0.01$ & - & -1.7 & -5.3 & 0.0123 & 0.2 & 41.6 & 7.6 & 0.5 & 50.1 & 4.28 & 17.08 \\
\hline \multirow{2}{*}{25} & \multirow{2}{*}{ Caoke } & \multirow{2}{*}{ D } & $08 / 10$ & 41.2 & 28.75 & $0.88 \pm 0.02$ & 0.88 & - & -11.9 & 0.0140 & 0.0 & 89.3 & 7.1 & 1.2 & 2.4 & 0.14 & - \\
\hline & & & 09/06 & 42.9 & 40.22 & $1.16 \pm 0.02$ & 1.16 & - & -12.3 & 0.0273 & 0.0 & 92.0 & 3.9 & 1.2 & 2.9 & 0.07 & - \\
\hline \multirow{2}{*}{26} & \multirow{2}{*}{ SMS } & & $08 / 10$ & 30.4 & 117.24 & $0.15 \pm 0.02$ & 0.14 & - & -14.3 & 0.0010 & 0.0 & 81.7 & 17.1 & 1.0 & 0.2 & 0.95 & - \\
\hline & & D & 09/06 & 31.3 & 2.97 & $1.2 \pm 0.09$ & 1.30 & - & -7.5 & 0.0072 & 0.0 & 90.1 & 8.5 & 1.1 & 0.2 & 0.02 & - \\
\hline & & & $08 / 06$ & 56.9 & - & $0.1 \pm 0.03$ & - & -29.3 & -19.1 & 1.9900 & 0.2 & 88.2 & 9.8 & 1.2 & 0.1 & - & 0.72 \\
\hline 27 & Gongyi & D & $08 / 10$ & 54.1 & 4028.44 & $0.05 \pm 0$ & 0.05 & -26.7 & - & 2.8800 & 0.4 & 95.8 & 0.5 & 1.5 & 0.0 & - & 1.98 \\
\hline & & & 09/06 & 55.4 & 1713.29 & $0.15 \pm 0.02$ & 0.15 & -27.6 & -2.9 & 3.2100 & 0.2 & 94.1 & 1.0 & 1.4 & 2.4 & - & 0.30 \\
\hline 28 & Xide & B & $09 / 06$ & 49.0 & 902.33 & $0.1 \pm 0.02$ & 0.10 & 16.6 & -8.8 & 0.3200 & 0.0 & 61.8 & 0.5 & 0.8 & 36.7 & 0.82 & - \\
\hline & & & $08 / 06$ & 47.7 & - & $0.13 \pm 0.00$ & - & 15.9 & -7.3 & 2.5100 & 0.6 & 81.5 & 0.2 & 1.2 & 15.0 & 0.03 & 1.31 \\
\hline 29 & Lizhou & B & $08 / 10$ & 48.1 & 1748.20 & $0.11 \pm 0.00$ & 0.11 & 18.6 & -9.8 & 2.0500 & 0.1 & 81.6 & 0.3 & 1.2 & 16.7 & 0.05 & 0.32 \\
\hline & & & 09/06 & 49.0 & 3557.33 & $0.11 \pm 0.00$ & 0.11 & 19 & -9.9 & 2.8200 & 0.5 & 80.6 & 0.8 & 1.1 & 15.6 & 0.04 & 1.15 \\
\hline & & & 08/06 & 49.8 & - & $2.22 \pm 0.03$ & - & - & -13.9 & 0.0018 & 0.0 & 87.8 & 10.9 & 1.0 & 0.4 & 0.07 & - \\
\hline 30 & Zhaojue & D & $08 / 10$ & 49.7 & 70.31 & $0.02 \pm 0.00$ & 0.01 & - & -13.4 & 0.0439 & 0.0 & 80.4 & 18.4 & 1.0 & 0.2 & 0.16 & - \\
\hline & & & 09/06 & 49.8 & 88.65 & $0.16 \pm 0.01$ & 0.15 & -3.3 & -13.8 & 0.0428 & 0.0 & 93.7 & 4.3 & 1.4 & 0.7 & 0.07 & - \\
\hline 31 & & D & 08/06 & 21.1 & - & $1.16 \pm 0.03$ & - & -58.8 & -21.1 & 0.0037 & 0.0 & 92.5 & 6.2 & 1.1 & 0.1 & 0.02 & - \\
\hline 31 & Taih & D & $08 / 10$ & 21.1 & 5.53 & $0.93 \pm 0.03$ & 0.91 & -50.0 & -11.6 & 0.0047 & 0.0 & 84.2 & 14.7 & 1.0 & 0.0 & - & - \\
\hline & & & $08 / 06$ & 43.2 & - & $0.22 \pm 0.01$ & - & - & -11.2 & 0.1810 & 0.0 & 83.5 & 4.1 & 1.0 & 11.3 & 0.20 & - \\
\hline 32 & Puge & B & $08 / 10$ & 43.7 & 341.97 & $0.04 \pm 0.00$ & 0.04 & - & -12.2 & 0.1650 & 0.0 & 85.3 & 2.5 & 1.0 & 11.3 & 1.22 & - \\
\hline & & & 09/06 & 43.8 & 391.33 & $0.07 \pm 0.00$ & 0.07 & - & -10.8 & 0.1720 & 0.3 & 84.6 & 3.9 & 1.0 & 10.1 & 0.60 & 17.80 \\
\hline
\end{tabular}

presented wide ranges of 0.9 - 94 and $0.1-10.1 \%$, respectively. The He concentrations varied from $1-32100 \mathrm{ppm}$ (Table 1).

Nitrogen was predominant in the dissolved gases (29.1 - 95.8 vol\%). The oxygen concentrations had a range of $0.5-20 \mathrm{vol} \%$. Those values indicate that $\mathrm{N}_{2}$ and $\mathrm{O}_{2}$ were mainly derived from air with consumption of $\mathrm{O}_{2}$ during water circulation. $\mathrm{CO}_{2}$ concentrations ranged from $0.1-64.7 \mathrm{vol} \%$, higher values were measured in the samples Nos.7, 14, and 24 from the XSHF zone, but low values $(0.2-3 \%)$ in the samples from the ANHF zone (Table 1). $\mathrm{CO}_{2}$ in the gas phase is positively correlated with the water temperature. The higher the water temperature is, the less $\mathrm{CO}_{2}$ is dissolved in water (Table 1), and the more $\mathrm{CO}_{2}$ is in the gas phase.

\subsection{Isotopic Ratios of $\mathrm{He}$ and $\mathrm{CO}_{2}$}

The measured ${ }^{3} \mathrm{He} /{ }^{4} \mathrm{He}$ ratios $\left(\mathrm{R}_{\mathrm{m}}\right)$ of the samples have a ranged of $0.02-5.3 \mathrm{Ra}$ ( $\mathrm{Ra}$ is atmospheric ${ }^{3} \mathrm{He} /{ }^{4} \mathrm{He}=1.4$ $\left.\times 10^{-6}\right)$. The $\mathrm{R}_{\mathrm{m}}$ values of the free gas samples were mostly greater than $1 \mathrm{Ra}$. Nevertheless, the $\mathrm{R}_{\mathrm{m}}$ values of the dissolved gas samples were found to be between $0.04-1 \mathrm{Ra}$. The $\mathrm{R}_{\mathrm{m}}$ ratios of the hot springs in the Kangding and Luding regions at the southeastern segment of the XSHF were higher than those in other locations (Fig. 2, Table 1).

The carbon isotopic ratios of both $\mathrm{CO}_{2}$ and $\mathrm{CH}_{4}$ varied spatially and temporally. Values of $\delta^{13} \mathrm{C}_{\mathrm{CO}_{2}}$ were in a wide range from $-21.1 \sim-1.9 \%$. The $\delta^{13} \mathrm{C}_{\mathrm{CO}_{2}}$ values decreased markedly from June 2008 to June 2009. The carbon 
isotopic ratios of methane $\left(\delta^{13} \mathrm{C}_{1}\right)$ in the spring gases ranged from -58.8 - 19\%o and were mostly around $-20 \%$ (Fig. 2, Table 1).

\section{DISCUSSION}

\subsection{Origins of ${ }^{4} \mathrm{He}, \mathrm{CO}_{2}$, and $\mathrm{CH}_{4}$}

Origins of gaseous components in the spring gases were discussed in order to calculate the contribution of mantlederived $\mathrm{He}$ and $\mathrm{CO}_{2}$ after the Wenchuan Ms 8.0 earthquake.

\subsection{1 ${ }^{4} \mathrm{He}$}

Helium in the hot springs had multiple origins that are illustrated by the $\mathrm{R}_{\mathrm{m}} / \mathrm{R}_{\mathrm{A}}$ plot and ${ }^{4} \mathrm{He} /{ }^{20} \mathrm{Ne}$ (Fig. 3), in which most data scattered in the mixture region of mantle, crustal and atmospheric origins. This is concordant with the previous results (Du et al. 2006). For estimating the proportions of mantle-derived helium $\left(\mathrm{He}_{\mathrm{m}}\right)$, it was proposed that the $R_{m}$ values should be corrected by the atmospheric value of ${ }^{4} \mathrm{He} /{ }^{20} \mathrm{Ne}$ ratio in order to exclude the atmospheric contamination (Duchkov et al. 2010). The $R_{m}$ values of the samples collected in June 2008 cannot be corrected because of lacking $\mathrm{Ne}$ isotopic compositions. The differences between the corrected $\left(R_{c}\right)$ He isotopic ratios and the $R_{m}$ values in the free gas samples were mostly less than 5\% in October 2008 and June 2009 (Table 1), indicating the atmospheric He contamination in the free gas samples can be neglected. The $\mathrm{R}_{\mathrm{c}}$ values are greater than the typical crustal ${ }^{3} \mathrm{He} /{ }^{4} \mathrm{He}(\mathrm{R} / \mathrm{Ra}=0.02)(\mathrm{An}-$ drews 1985), indicating the contribution of mantle-derived helium. Therefore, the proportion of mantle-derived helium in the samples can be estimated using the two-end member model for mantle and crustal helium. The maximum of the estimated $\mathrm{He}_{\mathrm{m}}$ values is $62 \%$ at Longtougou in June 2008 (Table 2).

The mantle-derived helium may come to the Earth's surface along the permeable high-angle XSHF (Fig. 1), without significant dilution by the crustal radiogenic helium, resulting in the emanation of high ${ }^{3} \mathrm{He}$ hot spring gases in Kangding and Luding regions. It is generally accepted that faults and fractures play a major role in the localization and evolution of hydrothermal systems. The XSHF extends for $350 \mathrm{~km}$ in a northwest-southeast direction. The width of the XSHF zone is variable from dozens of meters to several kilometers. The XSHF has a steep dip near the surface $\left(70-80^{\circ}\right)$, however, the dip direction is variable ( $\mathrm{Xu}$ et al. 2003). In comparison with XSHF, LMSF is unfavorable to emanate mantle-derived ${ }^{3} \mathrm{He}$. The 30 - $50 \mathrm{~km}$-wide Longmen Shan region consists of several large napes separated by a number of nearly parallel, NW-dipping thrust faults (Xu et al. 2003). These thrust faults have been identified as three major listric thrust fault zones, the Wenchuan-Maowen Fault, the Yingxiu-Beichuan Fault, and the Guanxian-Jiangyou Fault. These faults may merge downward with the Guanxian-Jiangyou Fault at depth (Chen and Wilson 1996).

\subsection{2 $\mathrm{CO}_{2}$}

The $\delta^{13} \mathrm{C}$ values of $\mathrm{CO}_{2}$, combined with $\mathrm{R}_{\mathrm{m}}$, indicate that $\mathrm{CO}_{2}$ has multiple crust and mantle origins. It is considered that $\mathrm{CO}_{2}$ with $\delta^{13} \mathrm{C}$ value more negative than $-14 \%$ o could originate from organic matter (Bergfeld et al. 2001). Dissolved inorganic carbon (DIC) and dissolved organic carbon (DOC) is composed of dissolved carbonate species $\left(\mathrm{H}_{2} \mathrm{CO}_{3}, \mathrm{HCO}_{3}^{-}\right.$, and $\left.\mathrm{CO}_{3}{ }^{2-}\right)$ in temperature- and $\mathrm{pH}$-dependent equilibrium with one another. Isotopic fractionation occurs during conversion from one species to another and dissolution of $\mathrm{CO}_{2}$ gas. The equilibrium carbon fractionation during $\mathrm{CO}_{2}$ gas dissolution in water is $-1.31 \pm 0.06 \%$ o at $5-25^{\circ} \mathrm{C}$ (Zhang et al. 1995). Therefore, $\delta^{13} \mathrm{C}_{\mathrm{CO}_{2}}$ values of less than $-22 \%$ from the hot springs in the LMSF zone indicated that $\mathrm{CO}_{2}$ was predominantly derived from sedimentary organic matter (Table 1 ). The $\delta^{13} \mathrm{C}_{\mathrm{CO}_{2}}$ values of the Permian-Triassic limestone samples ranged from $-1.5-2.7 \%$ in the western Sichuan (Cui et al. 2009). The free gas sample from the Chuanpanqiao hot spring occurred in a limestone area enriched in $\mathrm{CO}_{2}$, of which the $\delta^{13} \mathrm{C}$ value was $-1.9 \%$ in June 2008, indicating $\mathrm{CO}_{2}$ originated from the dissolution of limestone (Fig. 2, Table 1). The $\delta^{13} \mathrm{C}_{\mathrm{CO}_{2}}$ values of about $-6 \%$ indicated different origins of mixing marine limestone, metamorphic rocks and mantle-derived gases in MJF and XSHF zones (Table 1).

For determining relative contributions from the gas sources, $\delta^{13} \mathrm{C}$ values of the gas samples were plotted against their $\mathrm{CO}_{2}{ }^{3} \mathrm{He}$ ratios together with those of the three assumed sources (Fig. 4). The $\mathrm{CO}_{2} /{ }^{3} \mathrm{He}$ ratios of the free gas and dissolved gas (Fig. 2, Table 1) in the hot springs have a wider range $\left(3 \times 10^{5} \sim 1 \times 10^{12}\right)$ (Table 1$) . \mathrm{CO}_{2}{ }^{3} \mathrm{He}$ ratios of the bubble gas samples are concordant with or greater than that of the MORB $\left(2 \times 10^{9}\right)$ (Marty and Jambon 1987). The contributions of the three sources to the hot spring gases in western Sichuan Province were estimated using the method from the literature (Sano and Marty 1995) (Fig. 4, Table 2). The $\mathrm{CO}_{2} /{ }^{\beta} \mathrm{He}$ ratios of the samples Nos. $8,10,13,16,17,18,19$, and 23 at Chuanpanqiao, Mounigou, and in the Kangding region were larger than $10^{9}$, and had shown an increasing trend from June 2008 to June 2009 (Fig. 4). The crustal marine limestone contributions to the hot spring gases in western $\mathrm{Si}$ chuan Province were assessed to be larger than $80 \%$ of the total $\mathrm{CO}_{2}$ budget in the free gases. The mantle $\mathrm{CO}_{2}$ contribution was found to be less than $8.7 \%$. For example, more than $80 \%$ of the spring $\mathrm{CO}_{2}$ in the Kangding area was derived from limestone because the sedimentary basement of the Kangding region is mainly comprised of Mesozoic limestone (Qi et al. 2011). The highest mantle $\mathrm{CO}_{2}$ contribution (8.7\%) was found in the Guanding Spring with higher ${ }^{3} \mathrm{He} /{ }^{4} \mathrm{He}$ values (3.4 Ra). Sedimentary organic carbon is a minor contributor, as indicated by widespread travertine deposition throughout 
the region (Zhang and Hu 2000).

\subsection{3 $\mathrm{CH}_{4}$}

The $\delta^{13} \mathrm{C}_{1}$ values indicated that $\mathrm{CH}_{4}$ in the gas samples enriched in $\mathrm{CH}_{4}$ could be mainly derived from sedimentary organic matter (Table 1). The variation of the $\delta^{13} \mathrm{C}_{1}$ values in the hot spring gases may be attributed to the microbial process and metamorphic decomposition of organic matter. The $\delta^{13} \mathrm{C}_{1}$ values of the spring gases at the Anxian, Guyi, Longpugou, Taihe were more negative than $-20 \%$, indicating a biogenic carbon source (Dai et al. 2008). $\mathrm{The}^{\mathrm{CH}_{4}}$ and
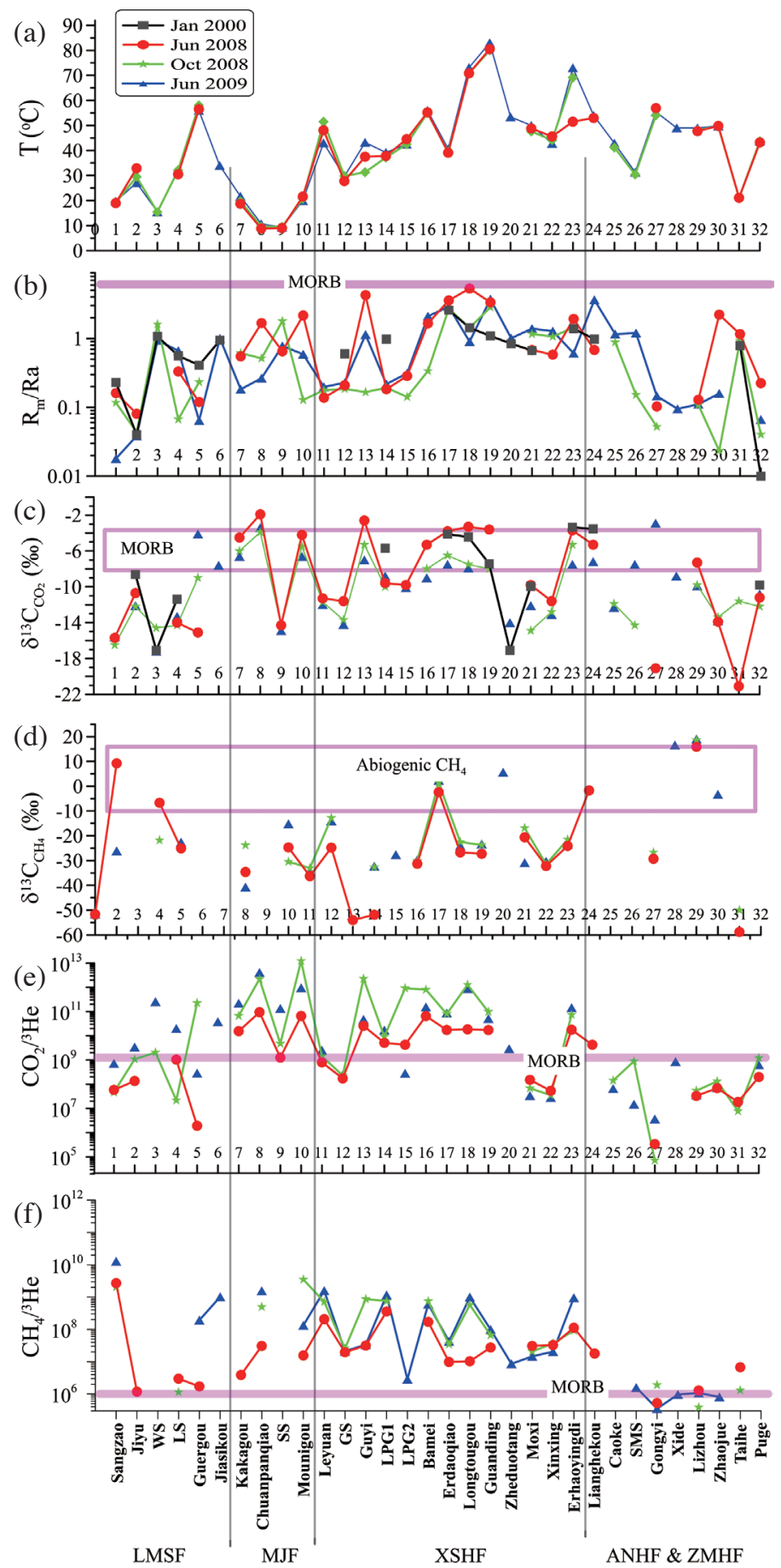

Fig. 2. Spatial-temporal variation of the temperature (a), $\mathrm{R}_{\mathrm{m}} / \mathrm{Ra}$ (b), $\delta^{13} \mathrm{C}_{\mathrm{CO}_{2}}$ (c), $\delta^{13} \mathrm{C}_{\mathrm{CH}_{4}}$ (d), $\mathrm{CO}_{2} /{ }^{3} \mathrm{He}$ ratio (e), and $\mathrm{CH}_{4} /{ }^{3} \mathrm{He}$ ratio (f) in the gas samples from hot springs in western Sichuan Province. The mantle end-members were marked with $\mathrm{R} / \mathrm{Ra}=8, \delta^{13} \mathrm{C}_{\mathrm{CO}_{2}}=-4 \pm 2 \%$, $\mathrm{CO}_{2} /{ }^{3} \mathrm{He}=2 \times 10^{9}$, $\delta^{13} \mathrm{C}_{\mathrm{CH}_{4}}=10^{6}$ (Marty and Jambon 1987; O'Nions and Oxburgh 1988) (black squares: sampling in January 2000, red circles symbols: sampling in June 2008; green pentagram symbols: sampling in October 2008, blue triangle symbols: sampling in June 2009). 


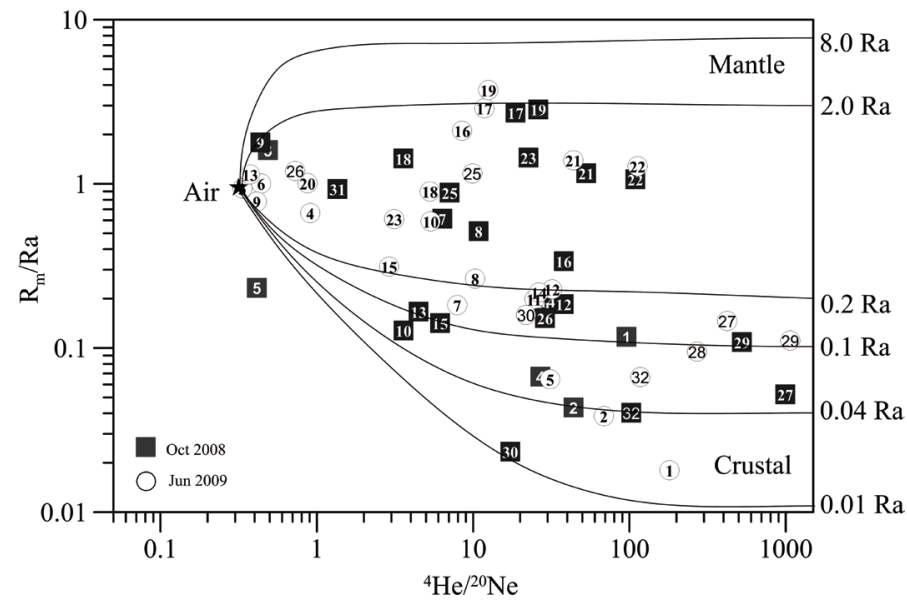

Fig. 3. Plot of ${ }^{3} \mathrm{He} /{ }^{4} \mathrm{He}$ versus ${ }^{4} \mathrm{He} /{ }^{20} \mathrm{Ne}$ ratios. Mixing lines between the atmosphere and upper mantle and the atmosphere and crust were calculated using the end members: air $\left({ }^{3} \mathrm{He} /{ }^{4} \mathrm{He}=1.4 \times 10^{-6},{ }^{4} \mathrm{He} /{ }^{20} \mathrm{Ne}\right.$ $=0.318)$ (Ozima and Podosek 1983), upper mantle $\left({ }^{3} \mathrm{He} /{ }^{4} \mathrm{He}=12 \times 10^{-6},{ }^{4} \mathrm{He} /{ }^{20} \mathrm{Ne}=100000\right)(\mathrm{Graham}$ 2002), old continental crust $\left({ }^{3} \mathrm{He} /{ }^{4} \mathrm{He}=0.02 \times 10^{-6}\right.$, $\left.{ }^{4} \mathrm{He} /{ }^{20} \mathrm{Ne}=100000\right)$ (Ballentine et al. 2005).

Table 2. Proportions of the $\mathrm{He}$ from mantle and the $\mathrm{CO}_{2}$ from mantle, limestone and sedimentary organism in hot spring gases in western Sichuan Province in the three samplings.

\begin{tabular}{|c|c|c|c|c|c|c|c|c|c|c|c|c|}
\hline \multirow{2}{*}{ NO. } & \multicolumn{3}{|c|}{$\mathrm{He}_{\mathrm{m}}(\%)$} & \multicolumn{3}{|c|}{$\mathrm{CO}_{2 \text { mantle }}(\%)$} & \multicolumn{3}{|c|}{$\mathrm{CO}_{2 \text { limestone }}(\%)$} & \multicolumn{3}{|c|}{$\mathrm{CO}_{2 \text { sedimentary }}(\%)$} \\
\hline & I & II & III & I & II & III & I & II & III & I & II & III \\
\hline 1 & 1.7 & 1.2 & 0.0 & - & - & - & - & - & - & - & - & - \\
\hline 3 & - & 25.8 & 8.8 & - & - & - & - & - & - & - & - & - \\
\hline 8 & 19.4 & 5.7 & 2.7 & 1.6 & 0.1 & 0.0 & 92.4 & 87.0 & 88.7 & 6.0 & 13.0 & 11.3 \\
\hline 10 & 25.0 & 0.4 & 6.5 & 2.3 & 0.0 & 0.1 & 84.2 & 81.7 & 77.9 & 13.5 & 18.3 & 21.9 \\
\hline 12 & 2.3 & 1.9 & 2.4 & - & - & - & - & - & - & - & - & - \\
\hline 13 & 49.7 & 1.1 & 19.8 & 5.8 & 0.1 & 3.1 & 86.8 & 82.3 & 74.2 & 7.4 & 17.6 & 22.6 \\
\hline 16 & 19.2 & 3.7 & 24.8 & 2.3 & 0.2 & 1.0 & 80.6 & 73.2 & 69.3 & 17.2 & 26.6 & 29.8 \\
\hline 17 & 41.5 & 31.8 & 34.1 & 8.6 & 1.9 & 1.7 & 80.6 & 76.9 & 73.7 & 10.8 & 21.2 & 24.6 \\
\hline 18 & 62.0 & 16.9 & 10.3 & 8.1 & 0.1 & 0.2 & 82.6 & 75.0 & 73.6 & 9.2 & 24.9 & 26.3 \\
\hline 19 & 38.9 & 11.5 & 44.1 & 8.7 & 1.5 & 2.9 & 81.2 & 72.2 & 72.8 & 10.1 & 26.3 & 24.3 \\
\hline 21 & 7.8 & 13.4 & 16.1 & - & - & - & - & - & - & - & - & - \\
\hline 23 & 22.3 & 11.5 & 6.6 & 8.5 & 2.0 & 1.0 & 81.1 & 80.8 & 74.2 & 10.5 & 17.2 & 24.7 \\
\hline 29 & 1.3 & 1.1 & 1.1 & - & - & - & - & - & - & - & - & - \\
\hline 32 & 2.5 & 0.3 & 0.6 & - & - & - & - & - & - & - & - & - \\
\hline
\end{tabular}

Note: I: Sampling in June 2008, II: Sampling in October 2008, III: Sampling in June 2009.

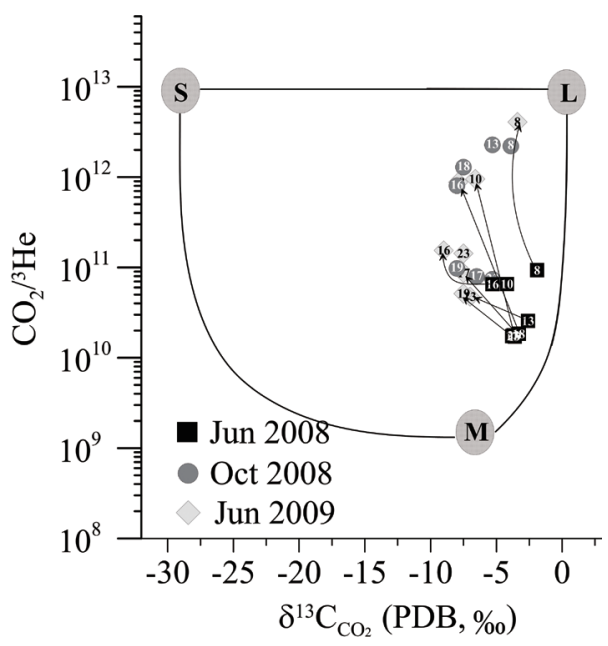

Fig. 4. Plot of $\mathrm{CO}_{2} /{ }^{3} \mathrm{He}$ vs. $\delta^{13} \mathrm{C}_{\mathrm{CO}}$, for the bubble gas samples in western Sichuan Province. The end-member compositions for sedimentary organic carbon (S), mantle carbon $(\mathrm{M})$, and lime stones $(\mathrm{L})$ are $\delta^{13} \mathrm{C}_{\mathrm{CO}_{2}}=-30$, -6.5 , and $0 \%$; and $\mathrm{CO}_{2}{ }^{3} \mathrm{He}=1 \times 10^{13}, 2 \times 10^{9}$, and $1 \times$ $10^{13}$, respectively (Sano and Marty 1995). The trajectories for binary mixing between $\mathrm{M}$ and $\mathrm{L}, \mathrm{M}$ and $\mathrm{S}$, and $\mathrm{L}$ and $\mathrm{S}$ are shown in the diagram; the square stands for the samples of June 2008, circles for the samples of October 2008 and diamonds for the samples of June 2009; arrow indicates the increasing trend of $\mathrm{CO}_{2}$ and ${ }^{4} \mathrm{He}$ concentrations and decreasing trend of ${ }^{3} \mathrm{He}$ concentration. 
$\mathrm{CO}_{2}$ in gas samples collected from the Qingzhu River in Qingchuan County, one of the regions affected by the 2008 Ms 8.0 giant Wenchuan Earthquake have typical biogenic signatures, with high $\mathrm{C}_{1} /\left(\mathrm{C}_{2}+\mathrm{C}_{3}\right), \delta^{13} \mathrm{C}_{1}(-56.1 \sim-56.6 \%$ ) $\delta \mathrm{D}_{\mathrm{CH}_{4}}\left(-328 \sim-345 \%\right.$ ) and $\delta^{13} \mathrm{C}_{\mathrm{CO}_{2}}(-6.7 \sim-4.9 \%)$. These measurements indicate that the gases are discharged from a shallow reservoir through faults or fractures caused by the earthquake (Zheng et al. 2013). The $\mathrm{CH}_{4}$ with a $\delta^{13} \mathrm{C}_{1}$ values between $-10 \sim-20 \%$ can be either of abiogenic or thermogenic origins. $\mathrm{CH}_{4}$ derived from post maturated coal has a $\delta^{13} \mathrm{C}$ value between -10 -30\%o (Dai et al. 2008). Carboniferous to Early-to-Middle Triassic limestone and Late Triassic coal-bearing strata (Xujiahe group) were found in the MJF, LMSF, and XSHF zones (Deng et al. 2012). Sample Nos. 8, 11, 14, 21, and 22 enriched in methane in the MJF and XSHF zones had $\delta^{13} \mathrm{C}$ values of $-10 \sim-30 \%$, indicating a mixture of abiogenic or thermogenic origins (Fig. 2, Table 1). $\mathrm{CH}_{4}$ in sample Nos.17, 20, 25, 29 with $\delta^{13} \mathrm{C}_{1}$ values less negative than $-10 \%$ found in the XSHF and ANHF zones was obviously abiogenic origin (Dai et al. 2008), which was supported by the ${ }^{3} \mathrm{He} /{ }^{4} \mathrm{He}$ and $\delta^{13} \mathrm{C}_{\mathrm{CO}_{2}}$ values (Table 1 ). $\mathrm{CH}_{4}{ }^{3} \mathrm{He}$ ratios in sample (Nos.1, 3, $8,13,16,17,18,19,21$, 22,23 ) indicated that $\mathrm{CH}_{4}$ was a mixture between mantle- derived volatiles $\left(\mathrm{CH}_{4}{ }^{3} \mathrm{He}=3 \times 10^{6}\right)$ and crustal volatiles $\left(\mathrm{CH}_{4}{ }^{3} \mathrm{He}=3 \times 10^{13}\right)($ Giggenbach et al. 1993; Jenden et al. 1993). The increase of $\mathrm{CH}_{4} /{ }^{3} \mathrm{He}$ ratios from June 2008 to June 2009 was attributed to the increase in biogenic and thermogenic $\mathrm{CH}_{4}$ in the spring gases (Fig. 2, Table 1).

\subsection{Correlation Between Gas Geochemistry and Seismic Activity}

In the Longmenshan seismic zone the increase in $\mathrm{R}_{\mathrm{m}} / \mathrm{Ra}$ and $\delta^{13} \mathrm{C}_{\mathrm{CO}_{2}}$ values in the spring gases at Wenchuan Seismostation after the Wenchuan Ms 8.0 earthquake indicated that more mantle-derived fluid migrated to the surface (Fig. 5). The $\mathrm{He}_{\mathrm{m}}$ was up to $25.8 \%$ (Table 2) in the sample collected in October 2008 at Wenchuan Seismostation at the hypocenter area. The geophysical data in LMSF also indicated that the lower velocity bodies under the main shock area and aftershocks in western Sichuan Province can be related to mantle fluid upwelling or partial melting (Lei and Zhao 2009; Zhang et al. 2009; Wang et al. 2010, 2011; Bai et al. 2011). Gas samples collected near the Gofukuji fault and its surrounding active faults are characterized by an increase in post seismic ${ }^{3} \mathrm{He} /{ }^{4} \mathrm{He}$ ratios in the main shock epicenter after the $\mathrm{M}_{\mathrm{w}} 5.4$
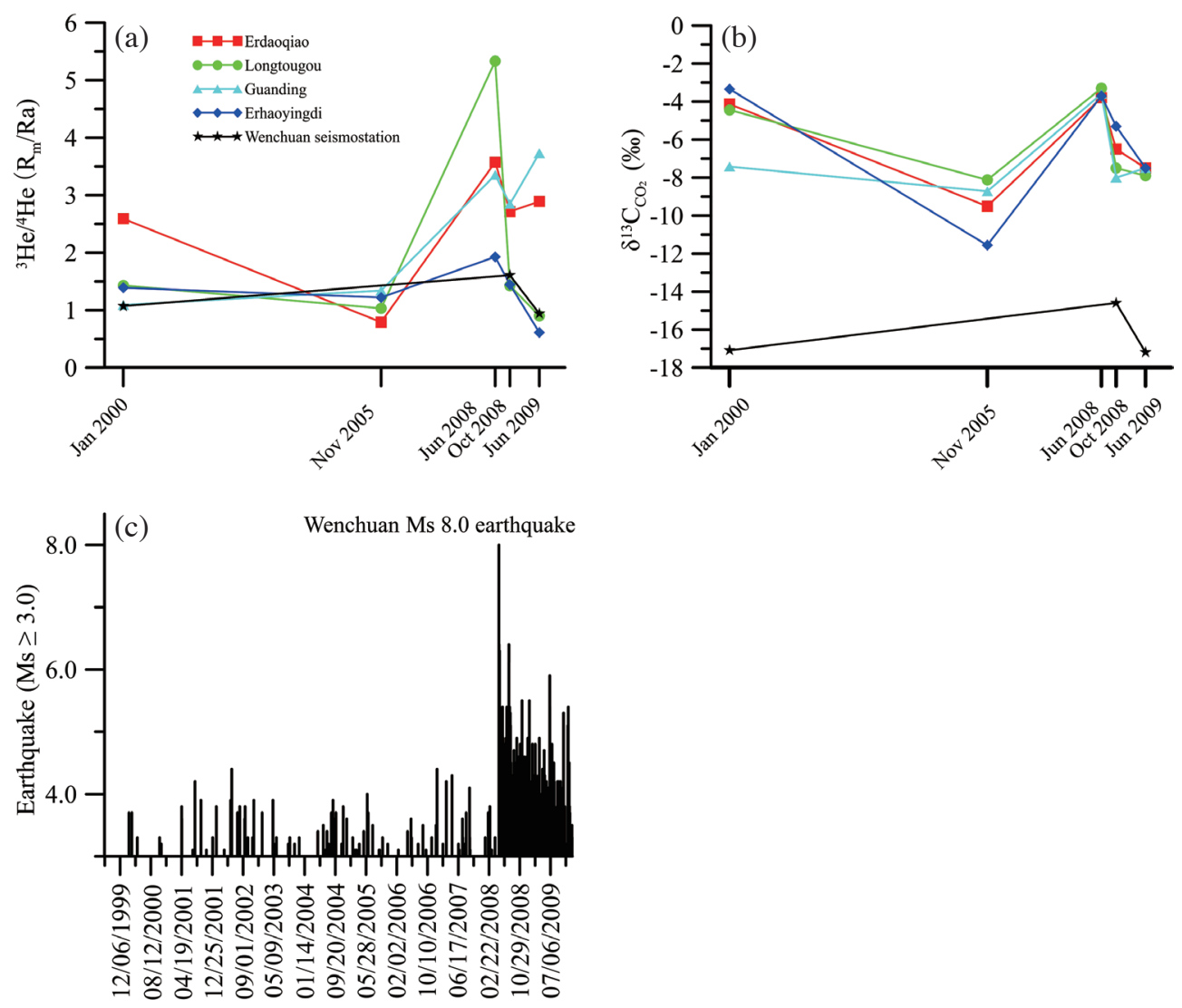

Fig. 5. Temporal variations of $\mathrm{R}_{\mathrm{m}} / \mathrm{Ra}$ values, $\delta^{13} \mathrm{C}_{\mathrm{CO}_{2}}$ values and earthquakes. $\mathrm{R}_{\mathrm{m}} / \mathrm{Ra}$ values (a) and $\delta^{13} \mathrm{C}_{\mathrm{CO}_{2}}$ values (b) in the spring gas samples were from Wenchuan seismo-station in the LMSF zone and those from the Kangding region of the XSHF zone in January 2000 (Du et al. 2006), November 2005 (Shen et al. 2007), June and October 2008, June 2009. (c) Earthquakes (Ms $\geq 3.0$ ) occurred from 1/1/2000 to 12/31/2009, in the area with longitude range from $102-105^{\circ}$, latitude range from $30-33^{\circ}$. 
central Nagano earthquake (Umeda et al. 2013).

In the XSHF zone, the evident increase of $\mathrm{R}_{\mathrm{m}} / \mathrm{Ra}$ ratios and $\delta^{13} \mathrm{C}$ values in June 2008 in the Kangding region from 2000 - 2009 indicated more mantle fluid contribution to the hot springs which were related to the enhanced degassing triggered by the Wenchuan Ms 8.0 earthquake (Figs. 5a, b). The proportions of $\mathrm{He}_{\mathrm{m}}$ in the samples of June 2008 at Longtougou, Erdaoqiao, and Guanding were 62, 41.5, and $38.9 \%$, respectively (Table 2). The $\delta^{13} \mathrm{C}_{\mathrm{CO}_{2}}$ and $\delta^{13} \mathrm{C}_{\mathrm{CH}_{4}}$ values for the gas samples of June 2008 in the Kangding regions (Table 1) indicated there was a percentage of mantle-derived fluid in the hot spring. The proportions of $\mathrm{CO}_{2 \text { mantle }}$ in the samples of June 2008 at Longtougou, Erdaoqiao, and Guanding were $8.1,8.6$, and $8.7 \%$, respectively (Table 2 ). In addition, the calculated high Poisson's ratio $(>0.30)$ of lithosphere in Kangding region where is the junction of the LMSF, XSHF, and ANHF zones could be attributed to mantle fluid contribution (Wang et al. 2010, 2011).

The $\mathrm{R}_{\mathrm{m}} / \mathrm{Ra}$ ratios and $\delta^{13} \mathrm{C}$ values in samples from the MJF in June 2008 were clearly higher than data obtained in June 2009, which might be attributable to the Wenchuan Ms 8.0 earthquake (Fig. 2). The proportions of $\mathrm{He}_{\mathrm{m}}$ in the samples of June 2008 at Chuanpanqiao and Mounigou were 19.4 and $25.0 \%$, respectively (Table 2 ).

From June 2008 to June 2009 , the $\mathrm{R}_{\mathrm{m}} / \mathrm{Ra}$ ratios and $\delta^{13} \mathrm{C}$ values from 5 springs with epicentral distances from $270-445 \mathrm{~km}$ in the ANHF and ZMHF zones significantly fluctuated, but did not show clear trends related to the Wenchuan Ms 8.0 earthquake and aftershocks. This indicated the effect of the great earthquake at distance was weaker.

The $\mathrm{R}_{\mathrm{m}} / \mathrm{Ra}$ and $\delta^{13} \mathrm{C}_{\mathrm{CO}_{2}}$ values of some hot springs in the LMSF, XSHF, and MJF zones showed a decreasing tendency after Wenchuan Ms 8.0 earthquake, as the aftershocks decreased (Fig. 5c). Over time, contribution of the mantle fluids to the hot springs gradually decreased, but the crustal gas components, radiogenic helium and $\mathrm{CO}_{2}$ and $\mathrm{CH}_{4}$ from organic origin increased relatively (Tables 1, 2). 4711 aftershocks with Ms $\geq 3.0$ were recorded during 12 May 2008 to 30 September 2009 in the LMSF zone, and magnitudes the aftershocks reduced gradually (Fig. 1). In addition, the magnitudes of the $\mathrm{He}$ and $\mathrm{H}_{2}$ anomalies of soil gas declined significantly with decreasing strength of the aftershocks with time in the seismic fault zone produced by the 12 May 2008 Wenchuan Ms 8.0 earthquake (Zhou et al. 2010).

The relationship between the mantle-derived fluid and seismic activity distribution were tangled and depend on active fault motions in western Sichuan Province. The deformation in western Sichuan Province is governed by interactions among three crustal blocks (Songpan, Chuandian, and South China) of distinctive rheological properties under the tectonic framework that eastward growth of the "soft" Eastern Tibet is blocked by the "hard" lithosphere of the South China block (Zhang 2013). The left-lateral XSHF continues to the north-south trending fault system without crustal shortening to form a bounding fault that limits the northern extend of the magnificent clockwise rotation of crustal material around the Eastern Himalaya Syntax. The relative motions among the brittle upper crustal blocks cause strain accumulations among their bounding faults to generate large earthquakes (Wang et al. 2011; Zhang 2013). The boundary faults (LMSF, XSHF, MJF, ANHF, ZMHF) among these three blocks in western Sichuan Province play an important role in generating devastating earthquakes with more than $80 \%$ of historical earthquakes having magnitude over 7.0 occurring along the boundary faults (Wen et al. 2008; Zhang 2013). There were several scenarios for upwelling mantle-derived fluids and the large earthquake in boundary faults in western Sichuan Province: (1) large earthquake induced the upwelling of more mantle-derived fluid into the crust and mixed with crustal fluid. (2) The emission of mantle-derived fluids through the crust towards the surface accompanied by an increase in temperature in the deeper reservoirs, which produced an increase in stress in the crust (Polyak et al. 1994; Gilat and Vol 2012). Consequently, the accumulation of thermal energy in the crust might induce deformation and trigger large earthquakes. (3) the permeability barriers in the reverse fault keep the permanent mantle fluid in flux in the upper mid-crust, resulting in highly over pressured fluids in the hypcentral area which trigger large earthquakes by weakening the rock strength over the accumulation and/or explode when the fluid pressure is larger than the strength threshold (Terakawa et al. 2012; Chen et al. 2013). The gas geochemical data in XSHF, MJF in June 2008 suggests the Wenchuan Ms 8.0 earthquake induced the upwelling of more mantle-derived fluid into the crust and mixed with crustal fluid, whereas, in LMSF, the relationship between the Wenchuan Ms 8.0 earthquake and mantlederived fluid need more evidence to confirm.

\section{CONCLUSION}

The variations in the isotopic ratios of helium, carbon and gas compositions of gases in the hot springs of western Sichuan Province lead to the following conclusions.

The $\mathrm{CO}_{2} /{ }^{3} \mathrm{He}, \mathrm{CH}_{4} /{ }^{3} \mathrm{He}, \mathrm{R}_{\mathrm{m}} / \mathrm{Ra}, \delta^{13} \mathrm{C}_{\mathrm{CO}_{2}}$, and $\delta^{13} \mathrm{C}_{\mathrm{CH}_{4}}$ values of hot springs in the LMSF, XSHF, and MJF zones in June 2008 indicated that more mantle-derived fluids migrated into the crust and mixed with crustal fluid after the Wenchuan Ms 8.0 earthquake. The maximum proportions of the estimated $\mathrm{He}_{\mathrm{m}}$ values were $62 \%$ at Longtougou. The $\mathrm{He}_{\mathrm{m}}$ was up to $25.8 \%$ (Table 2) in the sample of October 2008 at Wenchuan Seismostation in the hypocenter area. The maximum proportions of $\mathrm{CO}_{2}$ mantle in the samples of June 2008 at Guanding were $8.7 \%$, respectively.

The contribution of the mantle fluids to the hot springs gradually decreased with the decay of aftershocks in the LMSF, XSHF, and MJF zones, but the crustal gas components, radiogenic helium and $\mathrm{CO}_{2}$ and $\mathrm{CH}_{4}$ from organic 
origin increased relatively from June 2008 to June 2009.

Acknowledgements The authors are grateful to Prof. Fang Du for her help with field work. This research was supported by the National Science and Technology Support Program [CEA Key Laboratory of Earthquake Prediction (2013IES010102, 02092416)] and the Natural Science Foundation of China (41303076, 41403099, 41402298, and 41373059).

\section{REFERENCES}

Andrews, J. N., 1985: The isotopic composition of radiogenic helium and its use to study groundwater movement in confined aquifers. Chem. Geol., 49, 339-351, doi: 10.1016/0009-2541(85)90166-4. [Link]

Bai, Z., X. Tian, and Y. Tian, 2011: Upper mantle P-wave tomography across the Longmenshan fault belt from passive-source seismic observations along AbaLongquanshan profile. J. Asian Earth Sci., 40, 873882, doi: 10.1016/j.jseaes.2010.04.036. [Link]

Ballentine, C. J., B. Marty, B. S. Lollar, and M. Cassidy, 2005: Neon isotopes constrain convection and volatile origin in the Earth's mantle. Nature, 433, 33-38, doi: 10.1038/nature03182. [Link]

Bergfeld, D., F. Goff, and C. J. Janik, 2001: Carbon isotope systematics and $\mathrm{CO}_{2}$ sources in the Geysers-Clear Lake region, northern California, USA. Geothermics, 30, 303331, doi: 10.1016/S0375-6505(00)00051-1. [Link]

Bräuer, K., H. Kämpf, S. Niedermann, and G. Strauch, 2005: Evidence for ascending upper mantle-derived melt beneath the Cheb basin, central Europe. Geophys. Res. Lett., 32, L08303, doi: 10.1029/2004GL022205. [Link]

Bräuer, K., H. Kämpf, and G. Strauch, 2009: Earthquake swarms in non-volcanic regions: What fluids have to say. Geophys. Res. Lett., 36, L17309, doi: 10.1029/2009GL039615. [Link]

Burchfiel, B. C., Z. Chen, Y. Liu, and L. H. Royden, 1995: Tectonics of the Longmen Shan and Adjacent regions, central China. Int. Geol. Rev., 37, 661-735, doi: 10.1080/00206819509465424. [Link]

Cao, C., Z. Li, L. Du, and L. Li, 2011: Composition of natural gas analysis by gas isotope mass spectrometer and chromatography. Modern Sci. Instrum., 5, 103-106. (in Chinese)

Chen, J., X. Yang, Q. Duan, T. Shimamoto, and C. J. Spiers, 2013: Importance of thermochemical pressurization in the dynamic weakening of the Longmenshan Fault during the 2008 Wenchuan earthquake: Inferences from experiments and modeling. J. Geophys. Res., 118, 4145-4169, doi: 10.1002/jgrb.50260. [Link]

Chen, S. F., and C. J. L. Wilson, 1996: Emplacement of the Longmen Shan Thrust-Nappe Belt along the eastern margin of the Tibetan Plateau. J. Struct. Geol., 18, 413-430, doi: 10.1016/0191-8141(95)00096-V. [Link]
Cui, Y., J. Liu, and Y. Ezaki, 2009: Fluctuations of stable carbon isotopes around the Permian-Triassic boundary in Huaying of Sichuan, South China: Its characteristics and biogeochemical origin. Acta Scientiarum Naturalium Universitatis Pekinensis, 45, 461-471. (in Chinese)

Dai, J., C. Zou, S. Zhang, J. Li, Y. Ni, G. Hu, X. Luo, S. Tao, G. Zhu, J. Mi, Z. Li, A. Hu, C. Yang, Q. Zhou, Y. Shuai, Y.Zhang, and C. Ma, 2008: Discrimination of abiogenic and biogenic alkane gases. Sci. China Ser. D, 51, 1737 1749, doi: 10.1007/s11430-008-0133-1. [Link]

Deng, B., S. Liu, L. Jansa, J. Cao, Y. Cheng, Z. Li, and S. Liu, 2012: Sedimentary record of Late Triassic transpressional tectonics of the Longmenshan thrust belt, SW China. J. Asian Earth Sci., 48, 43-55, doi: 10.1016/j.jseaes.2011.12.019. [Link]

Du, J., W. Cheng, Y. Zhang, C. Jie, Z. Guan, W. Liu, and L. Bai, 2006: Helium and carbon isotopic compositions of thermal springs in the earthquake zone of Sichuan, Southwestern China. J. Asian Earth Sci., 26, 533-539, doi: 10.1016/j.jseaes.2004.11.006. [Link]

Du, J., X. Si, Y. Chen, H. Fu, C. Jian, and W. Guo, 2008a: Geochemical anomalies connected with great earthquakes in China. In: Stefánsson, Ó. (Ed.), Geochemistry Research Advances, Nova Science Publishers, New York, 57-92.

Du, J., Y. Zhang, and H. Li, 2008b: Advances in studies of thermal-fluid geochemistry and hydrothermal resource in China. In: Ueckermann, H. I. (Ed.), Geothermal Energy Research Trends, Nova Science Publishers, New York, 19-57.

Duchkov, A. D., K. M. Rychkova, V. I. Lebedev, I. L. Kamenskii, and L. S. Sokolova, 2010: Estimation of heat flow in Tuva from data on helium isotopes in thermal mineral springs. Russ. Geol. Geophys., 51, 209-219, doi: 10.1016/j.rgg.2009.12.023. [Link]

Favara, R., F. Italiano, and G. Martinelli, 2001: Earthquakeinduced chemical changes in the thermal waters of the Umbria region during the 1997-1998 seismic swarm. Terr. Nova, 13, 227-233, doi: 10.1046/j.13653121.2001.00347.x. [Link]

Giggenbach, W. F., Y. Sano, and H. Wakita, 1993: Isotopic composition of helium, and $\mathrm{CO}_{2}$ and $\mathrm{CH}_{4}$ contents in gases produced along the New Zealand part of a convergent plate boundary. Geochim. Cosmochim. Acta, 57, 34273455. doi: 10.1016/0016-7037(93)90549-C. [Link]

Gilat, A. L. and A. Vol, 2012: Degassing of primordial hydrogen and helium as the major energy source for internal terrestrial processes. Geosci. Front., 3, 911-921, doi: 10.1016/j.gsf.2012.03.009. [Link]

Graham, D. W., 2002: Noble gas isotope geochemistry of mid-ocean ridge and ocean island basalts: Characterization of mantle source reservoirs. In: Porcelli, D. P., C. J. Ballentine, and R. Wieler (Eds.), Noble Gases in Geochemistry and Cosmochemistry, Reviews in Mineralogy 
and Geochemistry, Vol. 47, Washington, 247-317.

Hilton, D. R., 1996: The helium and carbon isotope systematics of a continental geothermal system: Results from monitoring studies at Long Valley caldera (California, U.S.A.). Chem. Geol., 127, 269 -295, doi: 10.1016/0009-2541(95)00134-4. [Link]

Italiano, F., P. Bonfanti, M. Ditta, R. Petrini, and F. Slejko, 2009: Helium and carbon isotopes in the dissolved gases of Friuli Region (NE Italy): Geochemical evidence of $\mathrm{CO}_{2}$ production and degassing over a seismically active area. Chem. Geol., 266, 76-85, doi: 10.1016/j. chemgeo.2009.05.022. [Link]

Jenden, P. D., D. J. Drazan, and I. R. Kaplan, 1993: Mixing of thermogenic natural gases in Northern Appalachian Basin. AAPG Bull., 77, 980-998.

Lei, J. and D. Zhao, 2009: Structural heterogeneity of the Longmenshan fault zone and the mechanism of the 2008 Wenchuan earthquake (Ms 8.0). Geochem. Geophys. Geosyst., 10, Q10010, doi: 10.1029/2009GC002590. [Link]

Li, C. Y., Z. Y. Wei, J. Q. Ye, Y. B. Han, and W. J. Zheng, 2010: Amounts and styles of coseismic deformation along the northern segment of surface rupture, of the 2008 Wenchuan Mw 7.9 earthquake, China. Tectonophysics, 491, 35-58, doi: 10.1016/j.tecto.2009.09.023. [Link]

Li, Z. P., M. X. Tao, L. W. Li, Z. D. Wang, L. Du, and M. F. Zhang, 2007: Determination of isotope composition of dissolved inorganic carbon by gas chromatographyconventional isotope-ratio mass spectrometry. Chinese J. Anal. Chem., 35, 1455-1458, doi: 10.1016/S18722040(07)60089-9. [Link]

Li, Z. P., L. W. Li, M. X. Tao, C. H. Cao, L. Du, G. Wang, and Y. Xu, 2012: Development of combustion reactor furnace applied to compound specific of carbon isotope ratio analysis. Chinese J. Anal. Chem., 40, 1439-1444, doi: 10.1016/S1872-2040(11)60573-2. [Link]

Marty, B. and A. Jambon, 1987: C/ ${ }^{3} \mathrm{He}$ in volatile fluxes from the solid Earth: Implications for carbon geodynamics. Earth Planet. Sci. Lett., 83, 16-26, doi: 10.1016/0012821X(87)90047-1. [Link]

O'Nions, R. K. and E. R. Oxburgh, 1988: Helium, volatile fluxes and the development of continental crust. Earth Planet. Sci. Lett., 90, 331-347, doi: 10.1016/0012821X(88)90134-3. [Link]

Ozima, M. and F. A. Podosek, 1983: Noble Gas Geochemistry, Cambridge University Press, Cambridge, UK, $367 \mathrm{pp}$.

Polyak, B. G., M. D. Khutorskoi, I. L. Kamenskii, and E. M. Prasolov, 1994: Mass heat flow from the mantle in the Mongolian area (from helium isotope and geothermal data). Geokhimiya, 12, 1693-1705.

Qi, S., Q. Xu, B. Zhang, Y. Zhou, H. Lan, and L. Li, 2011: Source characteristics of long runout rock avalanches triggered by the 2008 Wenchuan earthquake, China. J. Asian Earth Sci., 40, 896-906, doi: 10.1016/j.jseaes.2010.05.010. [Link]

Ran, Y., L. Chen, J. Cheng, and H. Gong, 2008: Late Quaternary surface deformation and rupture behavior of strong earthquake on the segment north of Mianning of the Anninghe fault. Sci. China Ser. D, 51, 1224-1237, doi: 10.1007/s11430-008-0104-6. [Link]

Reber, S. D. and G. T. Cordes, 1995: Modifications to the Finnigan MAT 271 Mass Spectrometer in the Inorganic Gas Analysis Lab, Sandia Report SAND95-0961, Sandia National Laboratories, Albuquerque, New Mexico, 16 pp, doi: 10.2172/106522. [Link]

Ren, Z., A. Lin, and G. Rao, 2010: Late Pleistocene-Holocene activity of the Zemuhe Fault on the southeastern margin of the Tibetan Plateau. Tectonophysics, 495, 324-336, doi: 10.1016/j.tecto.2010.09.039. [Link]

Sano, Y. and B. Marty, 1995: Origin of carbon in fumarolic gas from island arcs. Chem. Geol., 119, 265-274, doi: 10.1016/0009-2541(94)00097-R. [Link]

Sano, Y., N. Takahata, G. Igarashi, N. Koizumi, and N. C. Sturchio, 1998: Helium degassing related to the Kobe earthquake. Chem. Geol., 150, 171-179, doi: 10.1016/ S0009-2541(98)00055-2. [Link]

Shen, L., D. Yuan, T. Ding, Y. Li, G. Le, and Y. Lin, 2007: Distributing inhomogeneity of helium isotope of $\mathrm{CO}_{2}$ degasification point and its geotectogenesis in southwest of China. Acta. Geologica. Sinica., 81, 475-487. (in Chinese)

Tang, R. and W. Han, 1993: Earthquake and Active Fault in Sichuan, Seismological Press, Beijing, 7-272. (in Chinese)

Tedesco, D. and P. Scarsi, 1999: Chemical (He, $\mathrm{H}_{2}, \mathrm{CH}_{4}$, $\mathrm{Ne}, \mathrm{Ar}, \mathrm{N}_{2}$ ) and isotopic ( $\left.\mathrm{He}, \mathrm{Ne}, \mathrm{Ar}, \mathrm{C}\right)$ variations at the Solfatara crater (southern Italy): Mixing of different sources in relation to seismic activity. Earth Planet. Sci. Lett., 171, 465-480, doi: 10.1016/S0012821X(99)00137-5. [Link]

Terakawa, T., S. A. Miller, and N. Deichmann, 2012: High fluid pressure and triggered earthquakes in the enhanced geothermal system in Basel, Switzerland. J. Geophys. Res., 117, B07305, doi: 10.1029/2011JB008980. [Link]

Umeda, K., Y. Sakagawa, A. Ninomiya, and K. Asamori, 2007: Relationship between helium isotopes and heat flux from hot springs in a non-volcanic region, Kii Peninsula, southwest Japan. Geophys. Res. Lett., 34, L05310, doi: 10.1029/2006GL028975. [Link]

Umeda, K., K. Asamori, and T. Kusano, 2013: Release of mantle and crustal helium from a fault following an inland earthquake. Appl. Geochem., 37, 134-141, doi: 10.1016/j.apgeochem.2013.07.018. [Link]

Wang, Z., D. Zhao, and J. Wang, 2010: Deep structure and seismogenesis of the north-south seismic zone in southwest China. J. Geophys. Res., 115, B12334, doi: 
10.1029/2010JB007797. [Link]

Wang, Z., J. Wang, Z. Chen, Y. Liu, R. Huang, S. Pei, Q. Zhang, and W. Tang, 2011: Seismic imaging, crustal stress and GPS data analyses: Implications for the generation of the 2008 Wenchuan Earthquake (M7.9), China. Gondwana Res., 19, 202-212, doi: 10.1016/j. gr.2010.05.004. [Link]

Weiss, R. F., 1971: Solubility of helium and neon in water and seawater. J. Chem. Eng. Data, 16, 235-241, doi: 10.1021/je60049a019. [Link]

Wen, X., S. Ma, X. Xu, and Y. He, 2008: Historical pattern and behavior of earthquake ruptures along the eastern boundary of the Sichuan-Yunnan faulted-block, southwestern China. Phys. Earth Planet. Inter., 168, 16-36, doi: 10.1016/j.pepi.2008.04.013. [Link]

Xu, X., X. Wen, R. Zheng, W. Ma, F. Song, and G. Yu, 2003: Pattern of latest tectonic motion and its dynamics for active blocks in Sichuan-Yunnan region, China. Sci. China Ser. D, 46, 210-226.

Yang, T. F., B. Marty, D. R. Hilton, and M. D. Kurz, 2009: Geochemical applications of noble gases. Chem. Geol., 266, 1-3, doi: 10.1016/j.chemgeo.2009.07.005. [Link]

Ye, X., M. Wu, and M. Sun, 2001: Determination of the noble gas isotopic composition in rocks and minerals by mass spectrometry. Rock Miner. Anal., 20, 174-178. (in Chinese)

Ye, X., M. Tao, C. Yu, and M. Zhang, 2007: Helium and neon isotopic compositions in the ophiolites from the Yarlung Zangbo River, Southwestern China: The in- formation from deep mantle. Sci. China Ser. D, 50, 801-812, doi: 10.1007/s11430-007-0017-9. [Link]

Zhang, J. and $\mathrm{H}$. $\mathrm{Hu}, 2000$ : The outgassing of the $\mathrm{CO}_{2}$ from the hot spring was quantitatively estimated along the $\mathrm{Xi}$ anshuihe deep fault zone in the western Sichuan province. Hydrogeol. Eng. Geol., 27, 19-21. (in Chinese)

Zhang, J., P. D. Quay, and D. O. Wilbur, 1995: Carbon isotope fractionation during gas-water exchange and dissolution of $\mathrm{CO}_{2}$. Geochim. Cosmochim. Acta, 59, 107114, doi: 10.1016/0016-7037(95)91550-D. [Link]

Zhang, P. Z., 2013: A review on active tectonics and deep crustal processes of the Western Sichuan region, eastern margin of the Tibetan Plateau. Tectonophysics, 584, 7-22, doi: 10.1016/j.tecto.2012.02.021. [Link]

Zhang, Z., Y. Wang, Y. Chen, G. A. Houseman, X. Tian, E. Wang, and J. Teng, 2009: Crustal structure across Longmenshan fault belt from passive source seismic profiling. Geophys. Res. Lett., 36, L17310, doi: 10.1029/2009GL039580. [Link]

Zheng, G., S. Xu, S. Liang, P. Shi, and J. Zhao, 2013: Gas emission from the Qingzhu River after the 2008 Wenchuan Earthquake, Southwest China. Chem. Geol., 339, 187-193, doi: 10.1016/j.chemgeo.2012.10.032. [Link]

Zhou, X., J. Du, Z. Chen, J. Cheng, Y. Tang, L. Yang, C. Xie, Y. Cui, L. Liu, L. Yi, P. Yang, and Y. Li, 2010: Geochemistry of soil gas in the seismic fault zone produced by the Wenchuan Ms 8.0 earthquake, southwestern China. Geochem. T., 11, doi: 10.1186/1467-486611-5. [Link] 